\title{
ASPEK HUKUM PERLINDUNGAN DESAIN INDUSTRIKERAJINAN KERANG MUTIARA DALAM PEMBERDAYAAN USAHA KECIL DI KOTA AMBON
}

\author{
Oleh: Muchtar A H Labetubun
}

\begin{abstract}
Agenda Intellectual Property Rights in particular the actual industrial designs among other things how the autonomous regional government can develop the potential of intellectual property rights owned by the community. Various potential intellectual property rights in the form of knowledge, skills and wisdom of local characteristics such as shellfish Craft Pearls can be protected and utilized for the greater good of society and regions. One potential intellectual property rights in the city of Ambon is the pearl handicraft products, therefore diligence pearl mussels need IPR protection and utilization of industrial design, especially for the greater public interest, especially Maluku Ambon City. Protection of industrial designs pearl handicraft products of the designers have not registered industrial design rights because many of those who do not know the first to file registration system adopted Industrial Design Law No. 31 of 2000, so that $n$ Trademark Copyright protection of intellectual property as an alternative to Craft Shells Of Pearls. Keywords: Protection Law, Industrial Design
\end{abstract}

\section{A. LATAR BELAKANG.}

Kemajuan dunia perdagangan tidak dapat dilepaskan dari pembangunan di bidang ekonomi yang pelaksanaannya dititikberatkan pada sektor industri. Salah satu kendala dalam melakukan pembangunan di Indonesia khususnya di bidang ekonomi, adalah faktor perangkat hukum yang masih perlu dikembangkan dan ditegakkan guna mengimbangi kebutuhan kemajuan masyarakat. Kemajuan dunia perdagangan berikut perangkatnya melesat meninggalkan perjalanan hukum nasional. Oleh karena itu, dalam era globalisasi perdagangan, pembangunan hukum di Indonesia diharapkan mampu mengantisipasi kemajuan di setiap sektor kehidupan masyarakat. ${ }^{1}$

$\begin{array}{crrr}\text { Ikut } & \text { serta } & \text { Indonesia } & \text { sebagai } \\ \text { anggota } & \text { WTO } & \text { (World } & \text { Trade }\end{array}$

Ranti Fauza Mayana, Perlindungan Desain Industri di Indonesia dalam Era Perdagangan Bebas, (Jakarta: Grasindo,2004), hal. 1
Organization) dan turut serta menandatangani Perjanjian Multilateral GATT Putaran Uruguay 1994, serta meratifikasi yang dituangkan dalam bentuk perundang-undangan, yaitu UndangUndang No. 7 Tahun 1994 tentang Pengesahan Agreement Estabilishing The Word Trade Organization (Persetujuan Pembentukan Organisasi Perdagangan Dunia) Maka konsekuensinya Indonesia harus berusaha menegakkan prinsip-prinsip pokok yang dikandung dalam General Agreement on Tariffs and Trade (GATT) tersebut termasuk didalamnya mencakup Trade Related Aspects of Intellectual Property Rights (TRIP's) yang intinya mengatur ketentuan-ketentuan di bidang Hak atas Kekayaan Intelektual (HaKI) yang harus dipatuhi dan dilaksanakan oleh negara-negara anggota yang akan diberlakukan mulai tanggal 1 Januari $1995 .^{2}$

2 Muhamad Djumhana; R. Djubaedillah, Hak Milik Intelektual, Sejarah Teori dan Prakteknya di Indonesia, (Bandung: Citra Aditya Bakti, 2003), hal. 18 
Pemerintah Indonesia kini telah menjadi anggota WTO sebagai konsekuensinya terikat penuh pada aturan TRIP's sehingga semata aturan HaKInya harus menyesuaikan dengan aturan TRTP's dan konvensi internasional HaKI yang menjadi substansinya (Full Compliance). Selain itu Indonesia mulai 1 Januari 2000 harus menjamin perlindungan HaKI yang berasal dari negara lain sama seperti melindungi HaKI yang berasal dari dalam negeri (National Treatment Principle). ${ }^{3}$ Selain hal di atas juga diperlukan adanya penegakan hukum yang konsisten.

Untuk mengakomodasi beberapa ketentuan dari hasil Putaran Uruguay tersebut, Indonesia melakukan revisi terhadap beberapa Undang-undang Hak Atas Kekayaan Intelektual, yaitu:

1. UU No. 6 Tahun 1982 tentang Hak Cipta yang direvisi menjadi UU No 7 Tahun 1987 kemudian UU No. 12 Tahun 1997 dan terakhir UU No. 19 Tahun 2002 tentang Hak Cipta

2. UU No.6 Tahun 1989 tentang Paten kemudian menjadi UUNo. 13 Tahun 1997 dan disempurnakan menjadi UU No. 14 Tahun 2001 tentang Paten

3. UU No. 21 Tahun 1961 di ubah menjadi UU No. 19 Tahun 1992 tentang Merek direvisi dengan dikeluarkannya UU No.14 Tahun 1997 dan kemudian disempurnakan menjadi UU No. 15 Tahun 2001 tentang Merek.

Indonesia masih harus melaksanakan kewajibannya menetapkan beberapa undang-undang di bidang HaKI lainnya yaitu Undang-Undang Desain Industri (Industrial Designs), Rahasia Dagang (Protection of Undisclosed Information), dan Semi Konduktor (Lay-out Designs of Integrated Circuits) serta Anti Persaingan Curang dalam Perjanjian Lisensi (Control of

Sentot Prihandajani Sigito, "Perlindungan dan Pemberdayaan Hak Kekayaan Intelektual Tradisional", Arena Hukum, Maret 2000; 10: 4, 114.

\section{Anty Competitive Practices in Contractual Licences). ${ }^{4}$}

Pada tahun 2000, Indonesia telah memiliki tiga undang-undang baru di bidang HaKI, yaitu UU No. 30 Tahun 2000 tentang Rahasia Dagang, UU No. 31 Tahun 2000 tentang Desain Industri, dan UU No. 32 Tahun 2000 tentang Desain Tata Letak Sirkuit Terpadu. Namun demikian, adanya usaha pemerintah tersebut belum mendapat hasil yang maksimal. Dalam kenyataannya, perlindungan HaKI di Indonesia masih lemah. Pada saat ini, kesadaran masyarakat akan HaKI sangat minim. Ini terbukti adanya banyak kasus pembajakan terhadap produk yang sudah dilindungi dengan hukum HaKI, menyebabkan produk-produk yang sebenarnya karya asli Indonesia dijiplak oleh pengusaha asing diantaranya terhadap desain industri kerajinan rotan, kayu dan batik, selain ini setidaknya ada 800-an motif perak tradisional Bali telah dipatenkan orang asing. "Sekitar 800 motif perak yang sebagian besar menggunakan motif tradisional Bali telah diklaim sebagai milik perusahaan orang asing 5 . Saat ini produkproduk tersebut tergolong salah satu produk unggulan ekspor Indonesia dari sektor non migas.

sudah tiga tahun berturut-turut dimasukkan dalam daftar negara yang diawasi (Priority Watch List) oleh Amerika Serikat, karena dinilai tidak mampu memberikan perlindungan hukum HaKI. Banyak pelanggaran HaKI yang terjadi seperti pembajakan VCD, Program Komputer, pembajakan merek terkenal seperti Levi's, Polo maupun pelanggaran

Yayasan Klinik HAKI (IP CliniC), Kompilasi Undang-undang Hak Cipta, Paten Merek dan Terjemahan Konvensi-konvensi di Bidang Hak atas Kekayaan Intelektual (HaKI), (Bandung: Citra Aditya Bakti, 2006), hal xv

5 Deden Gunawan . Karya RI Dipatenkan Asing; Berkarya di Tengah Ancaman Hukuman, http://www.detiknews.com, downloud tanggal 26 Juli 2009 
obat paten menjadi obat generik. Berdasarkan Special 301, United States Trade Representative (USTR) yang dipimpin oleh Charlene Barskefsky mengancam Indonesia untuk memberikan sanksi perdagangan atas komoditas garmen dan hasil bumi. ${ }^{6}$

Bertolak belakang dari kenyataan tersebut, Indonesia masih harus mensosialisasikan peraturan-peraturan tentang HaKI secara efektif kepada masyarakat khususnya pada dunia usaha, sebagai pihak yang langsung menerima dampak pemberlakuan HaKI tersebut sehingga kesadaran dan perlindungan hukum terhadap pemilik atau pemegang HaKI itu meningkat. Jika pelanggaran HaKI ini terus berlanjut, maka tidak menutup kemungkinan Indonesia dapat saja diajukan ke Panel WTO dan akan menerima sanksi dari WTO apabila terbukti jelek dalam perlindungan HaKInya. Akibat terburuk dari sanksi ini adalah penolakan masuk atau pembatasan kuota atas produk Indonesia ke suatu negara. Jika hal ini terjadi maka Indonesia akan kesulitan dalam memasarkan produknya.

Salah satu sektor yang akan terkena imbasnya adalah sektor usaha kecil, yang salah satunya adalah kerajinan kerang mutiara. Para pengrajin akan kesulitan memasarkan hasil kerajinannya. Apalagi nanti dalam menghadapi pasar bebas dunia, ataupun menyongsong berlakunya pasar bebas ASIAN/AFTA. Cepat atau lambat para pengrajin kerang mutiara harus berbenah diri untuk lebih mempersiapkan serta memperbaiki segala sistem penunjang kelayakan hidup dari pengrajin kerang mutiara. Hal ini adalah mutlak dilakukan mengingat bahwa pada era perdagangan bebas, hasil produksi dari pengrajin kerang mutiara harus memenuhi standart internasional

\footnotetext{
6 Menteri Perindustrian dan Perdagangan, "Sambutan Pengarahan Menperindag pada RAKORNAS RISTEK", disenggarakan oleh Kantor Menristek tanggal 10-12 Agustus 1999
}

dalam hal mutu dan kualitas serta melindungi produknya dengan hukum HaKI khususnya Desain Industri, sehingga produk mereka mempunyai daya saing di pasaran dan mampu bersaing di era pasar bebas nanti. Untuk itu perlu adanya pembinaan dari instansi terkait terhadap mereka.

Jika selama ini, peranan dalam menghadapi persaingan global mendatang lebih banyak mengharapkan pada kalangan dunia usaha yang berada di kota-kota besar terutama Jakarta maka harapan terhadap kemampuan dan potensi daerah harus pula dilakukan. Melibatkan potensi daerah yang sesungguhnya tempat di mana sumber daya alam itu berada, dan potensi-potensi sumber daya manusianya yang selama ini kurang dilibatkan maka kekuatan nasional akan dapat digalang lebih baik lagi . ${ }^{7}$

Apalagi berlakunya undang-undang otonomi daerah yang telah diamanatkan oleh Undang-Undang Nomor 32 Tahun 2004 tentang Pemerintahan Daerah yang disebutkan dalam Pasal 12 (1) yaitu bahwa salah satu urusan wajib yang menjadi kewenangan pemerintah daerah untuk Kabupaten/Kota adalah fasilitas pengembangan koperasi, usaha kecil dan menengah. Daerah berwenang untuk mengatur dan mengurus rumah tangganya sendiri. Untuk itu daerah harus meningkatkan perekonomian daerah, sehingga daerah diharapkan mampu membiayai secara mandiri urusan - urusan rumah tangganya sebagaimana dalam Undang-Undang Nomor 33 Tahun 2004 tentang Perimbangan Keuangan Pusat dan Daerah yang mewajibkan bagi daerah untuk mengelola secara mandiri pemerintahannya sendiri termasuk mengenai pendapatan dan pengeluaran daerah.

Pelaksanaan otonomi daerah sekarang ini maka dikaitkan dengan perlindungan hukum terhadap HaKI

\footnotetext{
7 Yayasan Klinik HAKI (IP CliniC), Op. Cit., hal.
} xvii 
khususnya produk-produk usaha kecil yang berpotensi terhadap HaKI antara lain bagaimana pemerintah daerah otonom dapat mengembangkan potensi HaKI yang dimiliki oleh usaha kecil, salah satunya berupa desain industri kerajinan kerang mutira yang dilindungi dan dimanfaatkan sebesar-besarnya bagi kepentingan masyarakat dan pemerintah daerah.

Pemerintah daerah harus melakukan upaya untuk menggali dan mengembangkan potensi masyarakat setempat, sehingga dengan menggali dan berusaha mengembangkan potensi yang ada, maka diharapkan mampu meningkatkan taraf perekonomian masyarakat. Sehingga dapat memberikan makna bahwa untuk dapat lebih maju dan berkembang, upaya perlindungan hukum HaKI atas desain industri terhadap kerajinan kerang mutiara yang digeluti oleh usaha kecil tidak hanya diserahkan kepada pemiliknya, namun diperlukan juga perhatian dan perlindungan dari pemerintah Kota Ambon .

Usaha kerajinan mutiara di kota Ambon dalam perkembangannya masih berupa usaha skala kecil yang masih membutukan pemberdayaan untuk meningkatkan dan mengembangkan produk kerajinan kerang mutiara terhadap mutu dan kualitas serta perlindungan dengan hukum HaKI atas desain industri, sehingga produk kerajinan kerang mutiara dari Ambon mempunyai daya saing di pasaran dan mampu bersaing dalam era pasar bebas.

\section{B. PEMBAHASAN}

\section{Pemberdayaan Usaha Kecil Kerajinan Kerang Mutiara}

Pengrajin kerang mutiara sebagai skala usaha kecil sebagaimana Usaha kecil menurut Departemen Perindustrian dan Perdagangan (DEPERINDAG) bersama Biro Pusat Statistik (BPS) mendefinisikan dan Undang-Undang UMKM, diantaranya: "Kegiatan ekonomi yang dilakukan oleh perseorangan atau badan yang bertujuan untuk memproduksi barang atau jasa untuk diperniagakan secara komersial, yang memiliki nilai penjualan pertahun lebih besar Rp 1 milyar namun kurang dari Rp 50 milyar, dan batasan mengenai skala usaha berdasarkan criteria jumlah tenaga kerja 5-19 orang dikategorikan sebagai usaha kecil."

Bank Indonesia melalui Surat Edaran Bl No.3/9/BKr, tanggal 17 Mei 2001 memberikan batasan usaha kecil, yaitu:

a) Memiliki kekayaan bersih paling banyak Rp. 200 juta tidak termasuk tanah dan bangunan tempat usaha, atau

b) Memiliki hasil penjualan tahunan paling banyak Rp 1 milyar

c) Milik warga negara Indonesia

d) Berdiri sendiri, bukan merupakan anak perusahaan atau cabang perusahaan yang dimiliki, dikuasai atau berafiliasi baik langsung maupun tidak langsung dengan usaha menengah atau usaha besar

e) Berbentuk usaha perseorangan, badan usaha yang tidak berbadan hukum atau badan usaha yang berbadan hukum, termasuk koperasi."

Berdasarkan Undang-Undang

Nomor 20 Tahun 2008 Tentang Usaha Mikro, Kecil, dan Menengah yang disebutkan dalam Pasal 6 ayat (2) Bahwa:

"Kriteria usaha kecil adalah memiliki kekayaan bersih lebih dari Rp.50,000.000 (lima puluh juta rupiah) sampai dengan paling banyak Rp 500.000.000 (lima ratus juta rupiah) selain tanah dan bangunan tempat usaha atau memiliki hasil penjualan tahunan Iebih dari Rp. 300.000.000 (tiga ratus juta rupiah) sampai dengan paling banyak Rp. 2.500.000.000 (dua milyar lima ratus juta rupiah)"

UKM sebenarnya dapat disebut sebagai motor penggerak perekonomian masyarat. Meskipun saat krisis juga terkena dampaknya, namun dapat dikatakan lebih solid dibandingkan usaha berskala besar. Saat ini, UKM merupakan salah satu

Syahlan A Sume, "Manajemen Usaha kecil \& Menengah", Modul I Pusat Pengembangan Bahan Ajar-UMB, tanpa tahun, hal 7 
kekuatan yang diandalkan untuk dapat bersaing sejak berlakunya AFTA (Asean Free Trade Are). Hal ini tidak berlebihan sebab produk-produk UKM, seperti kerajinan tangan, furnitur, produk kayu, mainan, tekstil, dan kulit memeiliki keunggulan komparatif dibandingkan produk negara lain. Keunggulan komparatif antara lain harga yang murah dan desain yang beragam serta unik. ${ }^{2}$ Sisi lain, ternyata UKM memiliki kekuatan yang sangat besar dan potensial. Terbukti mereka masih mampu bertahan hidup walaupun badai krisis ekonomi menerpa bangsa kita hampir beberapa tahun ini . kekuatan atau potensi tersebut adalah tidak birokratis dan mandiri, cepat tanggap dan fleksibel, dinamis dan ulet. $^{3}$

Sejak diberlakukannya Undangundang Nomor 31 Tahun 2000 tentang Desain Industri, para pendesain yang berasal dari kelompok Usaha Kecil dan Menengah (UKM) yang menguasai hampir $90 \%$ pelaku usaha di Indonesia diharapkan dapat memanfatkan perlindungan desain industri tersebut, kelompok UKM tersebut belum sepenuhnya memanfaatkan perlindungan desain industri yang sebenarnya dapat memajukan usaha mereka ${ }^{4}$, kondisi belum banyak permohonan perlindungan desain industri dari usaha kecil kerajinan kerang mutiara mengingat kekayaan ragam desain yang dimiliki oleh usaha kecil kerajinan kerang mutiara.

2 Hersugondo, "Pengembangan Usaha Kecil yang Berdaya Saing: Antara Kendala dan peluang", Gema STIKUBANK, Juni 1999; 31; III, 40. Sebagaimana yang dikutip Yoan Nursari Simanjuntak, Hak Desain Industri: Sebuah Realitas Hukum dan Sosial, (Surabaya: Srikandi, 2006), hal.110-111

3 BN Marbun. Kekuatan dan Kelemahan Perusahaan Kecil: Mengapa Ribuan Perusahaan Kecil Rontok Setiap Tahun, (Jakarta: Pustaka Binaman Pressindo, 1993), hal. 34

4 Ansori Sinungan, Perlindungan Desain Industri: Tantangan dan Hambatan Dalam Praktiknya di Indonesia, Disertasi Program Doktor Ilmu Hukum Pascasarjana Universitas Indonesia, Depok, 2009
Berkembangnya usaha kerajinan kerang mutiara tentunya tidak bisa terlepas dari upaya Pemerintah Kota Ambon untuk memberdayakan pengrajin agar bisa bertahan dalam memasarkan dan berkreasi untuk menghasilkan produk-produk kerajinan kerang mutiara yang berkualitas sekaligus memberikan kesan estetis. Secara teoritis pola pendekatan dalam pemberdayaan usaha kecil dan menengah yang umumya diwujudkan dalam berbagai bentuk penawaran program kegiatan:

a) Penawaran/bantuan modal;

b) Penawaran/bantuan alat-alat kerja;

c) Penawaran/bantuan teknik melalui pelatihan;

d) Penyelenggaraan kursus-kursus dalam upaya meningkatkan kerampilan SDM

Pasal 25 huruf (a) Undang-Undang Nomor 32 Tahun 2004 tentang Pemerintah Daerah menyebutkan bahwa kepala daerah mempunyai tugas dan wewenang memimpin penyelenggaraan pemerintahan daerah berdasarkan kebijakan yang ditetapkan bersama DPR. Dasar acuannya adalah berbagai dokumen perencanaan daerah yang berupa:

a) Anggaran Pendapatan Belanja Daerah (APBD)

b) Rencana Pembangunan Jangka Panjang (RPJP)

c) Rencana Pembangunan Jangka Menengah (RPJM)

d) Rencana Kerja Pembangunan Daerah (RKPD)

Pemerintah

memfasilitasi penyelenggaraan otonomi daerah, yang dimaksud dengan memfasilitasi adalah upaya memberdayakan daerah otonom melalui pemberian pedoman, bimbingan, pelatihan, dan arahan. ${ }^{5}$ Dalam Pasal 14 ayat (1) huruf (i) Undang-Undang Nomor 32 Tahun 2004 tentang Pemerintah Daerah disebutkan bahwa salah satu urusan wajib

Deddy S Bratakusumah; Dadang Solihin, Otonomi Penyelenggaraan Pemerintah Daerah, (Jakarta: Gramedia Pustaka Utama, 2003), hal. 29 
yang menjadi kewenangan pemerintah daerah untuk kabupaten/kota adalah fasilitasi pengembangan koperasi, usaha kecil dan menengah.

Pemberdayaan industri kerajinan kerang mutiara untuk kalangan usaha kecil merupakan salah satu agenda pemberdayaan yang umumnya berupa program kegiatan pemberdayaan yang diarahkan pada kelompok usaha kecil-menengah, berupa program-program kegiatan pembinaan yang diarahkan pada kelompok IKM yang merupakan penjabaran dari agenda Pembinaan dan pembangunan industri kecil yang diatur dalam Bab VI Tentang Arah Kebijakan Umum Pembangunan Kota Ambon sebagai lampiran dari Pasal 2 Perda Kota Ambon Nomor 2 Tahun 2007 Tantang Rencana Pembangunan Jangka Menengah (RPJM) Kota Ambon Tahun 2006-2011, yang menyebutkan:

1) Membina dan mengembangkan industri kecil dan menengah melalui bantuan modal usaha, pelatihan dan pendampingan teknis.

2) Peningkatan daya saing produk industri kecil dan menengah yang memanfaatkan potensi sumberdaya alam lokal dan bercorak budaya lokal.

3) Meningkatkan kegiatan penelitian dan pengembangan potensi local dalam rangka diversifikasi produk industri kecil dan menengah yang berciri lokal.

4) Mengembangkan mekanisme wajib uji sebagai bentuk pengawasan terhadap produk-produk industri dan pengawasan terhadap barang beredar.

5) Meningkatkan upaya kerjasama dalam melakukan promosi produkproduk industri kecil dan menengah secara berkala baik lokal, regional, nasional maupun internasional.

6) Peningkatkan kapasitas SDM di bidang perindustrian secara bertahap.

7) Memantapkan sistem distribusi barang dan jasa secara efektif dan efisien untuk menjamin stabilitas pemenuhan kebutuhan masyarakat dan sekaligus menekan laju inflasi.
8) Membina dan mengembangkan manajemen usaha bagi pelaku usaha dalam rangka tertib usaha dan perlindungan konsumen.

9) Peningkatan sistem informasi yang memudahkan pengambilan kebijakan di bidang perindustrian dan perdagangan.

10) Mengoptimalkan sumber PAD di bidang industri dan perdagangan."

Pembinaan yang dilakukan oleh Dinas Perindustrian dan Perdagangan Kota Ambon sebagai dinas yang berwewenang dalam pembinaan atau pemberdayaan terhadap industri kecil menengah sebagaimana yang diamanatkan dalam Pasal 2 Perda Kota Ambon Nomor 2 Tahun 2007 tersebut, melalui penjabaran pembinaanpembinaan:

a. Pemasaran, Mengikutsertakan pengrajin dalam Pameran Dalam Negeri maupun maupun Luar Negeri.

b. Produksi, Pemberian rekomendasi agar pengrajin lebih mudah dalam memperoleh bahan baku dan sekaligus arahan mengenai kualitas bahan baku yang bagus.

c. Bantuan Peralatan, bantuan alat-alat yang sesuai dengan kebutuhan usaha

d. Program Kemitraan, suatu kemitraan usaha dalam hal bantuan modal kepada pengrajin, Pemerintah Kota Ambon dalam hal ini hanya bertindak sebagai pemberi rekomendasi dan penengah antara pengrajin dan kemitraan tersebut

e. Studi Banding, ini dimaksudkan sebagai bahan perbandingan, bahan masukan guna pengembangan usaha dan guna menambah khasanah pengetahuan pengrajin mengenai perkembangan dan macam-macam desain kerajinan kerang mutiara

f. Penyuluhan, dapat dilaksanakan dalam bentuk:

1) Manajemen usaha dan pemasaran: Pemberian pelatihan tentang mengembangkan usaha, dan pemberian pelatihan tentang pemasaran yang baik 
2) Pelatiahan Desain: Memberikan pelatihan mengenai perkembangan desain

3) Sosalisasi Undang-Undang: Memberikan sosislisasi mengenai Undang-Undang HaKI di Indonesia. Program pembinaan tersebut, Pemerintah Kota Ambon melalui Dinas Perindustri dan Perdagangan Kota Ambon selaku fasilitator bagi pengrajin kerang mutiara untuk merealisasikan pembinaan kepada industri kecil menengah sebagai rencana program Disperindag Kota Ambon.

\section{Bentuk Perlindungan Desain Industri Kerajinan kerang Mutiara}

Desain-desain kerajinan kerang
mutiara semakin berkembang dan bermacam-macam bentuk atau motifnya, hal ini sebagai hasil pembinaan ${ }^{6}$ dari Pemkot Ambon mengenai pelatihan desain dan didukung dengan adanya kemauan dari pengrajin untuk terus berkreasi. Keunggulan kualitas kerajinan kerang mutiara terletak pada memberikan kesan estetis berupa pola dua dimensi dan ketahanan atau kualitas bahan bakunya (kerang mutiara). Keunggulan tersebut didukung dengan tersedianya sumber daya alam mutiara di laut Maluku yang bersifat budidaya dan alami. Desain-desain kerajinan kerang mutiara yaitu, Kembang, Burung Cendrawasi, Anatomi Muka, Akuarium, Kaligrafi, Perjamuan Kudus, Kereta Kencana, Kuda Liar, Merpati, Ayam dan, Perahu Layar.

Bentuk atau motif desain kerajinan kerang mutiara sebagaimana gambar di atas sampai saat ini belum memperoleh perlindungan HaKI secara umum. Pembuatan desain kerajinan kerang mutiara didasarkan pada inspirasi pribadi (karya pribadi), warisan dari pemilik lama, berdasarkan pesanan dari konsumen dan desain yang sedang diminati masyarakat. Kerajinan kerang mutiara dari sisi estetis

6 Lihat Pemberdayaan Desain Industri KKM oleh Pemkot Ambon atau seninya dan ukuran besar atau kecil menjadi prasyarat utama dalam penentuan harga, semakin indah dan ukuran suatu kerajinan kerang mutiara semakin tinggi harga yang dapat ditawarkan.

Secara teoritis, bentuk perlindungan haki atas desain industri kerajinan kerang mutiara, pengrajin dapat merasakan dari adanya perlindungan HaKI yang diberikan oleh Negara atas dasar permohonan pendaftaran kepada pendesain atau pemohon pendaftaran, selain memberikan kepastian hukum, juga memberikan manfaat khususnya manfaat ekonomi (berupa royalti) dan dapat melindungi pengrajin dari adanya peniruan, pembajakan, penjiplakan maupun perbutan curang lainnya yang dilakukan oleh orang lain atas karya-karya pengrajin yang berhak. Menurut Muhamad Djumhana dan R. Djubaedillah bahwa, secara garis besarnya beberapa keuntungan dan manfaat atau kegunaan yang dapat diharapkan dengan adanya perlindungan HaKI tersebut, yaitu diantaranya: ${ }^{9}$

a) Perlindungan HaKI yang kuat dapat memberikan dorongan untuk meningkatkan landasan teknologi (technological base) nasional guna memungkinkan pengembangan teknologi yang lebih cepat lagi.

b) Pemberian perlindungan hukum terhadap HaKI pada dasarnya dimaksudkan sebagai upaya untuk mewujudkan iklim yang lebih baik bagi tumbuh dan berkembangnya gairah mencipta atau menemukan sesuatu di bidang ilmu pengetahuan, seni dan satra.

c) Pemberian perlindungan hukum terhadap HaKI bukan saja merupakan pengakuan negara terhadap hasil karya dan karsa manusia, melainkan secara ekonomi makro merupakan penciptaan suasana yang sehat untuk menarik penanaman modal asing, serta

9 Muhamad Djumhana; R. Djubaedillah, .Op. Cit, hal. 32 
memperlancar internasional.

d) Selain itu, perlidungan HaKI khususnya desain industri bagi pendesain atau hak atas desain industri memperoleh keuntungan untuk promosi desain seluruh dunia.

Secara legal, kerajinan kerang mutiara telah memenuhi unsur-unsur sebagai suatu desain industri sebagaimana yang terdapat dalam pengertian desain industri pada 1 ayat (1) Undang-Undang Nomor 30 Tahun 2000 tentang Desain Industri, yaitu:

1) Merupakan suatu kreasi mengenai bentuk, konfigurasi, komposisi garis dan warna;

2) Member kesan estetis atau menampilkan keindahan;

3) Berbentuk dua atau tiga dimensi;

4) Dapat dipakai untuk menghasilkan suatu produk/barang.

Meskipun kerajinan kerang mutiara telah memenuhi unsur-unsur sebagai obyek desain industri tetapi akan sulit bagi pendesain kerajinan kerang mutiara ini untuk mendapatkan perlindungan secara hukum, mengingat adanya bebarapa hal yang akan menjadi penghambat saat didaftarkan, yaitu mengenai:

1) Syarat kebaruan

2) Kepemilikan

3) Publik domein

Berdasarkan syarat kebaruan yang tercantum dalam Pasal 2 ayat (1) dan ayat (2) UU Desain Industri, akan sulit bagi kerajinan kerang mutiara ini untuk mendapatkan perlindungan jika didaftarka karena secara mayoritas desain kerajinan kerang mutiara telah dipakai secara meluas di kalangan pendesain kerang mutiara khsusnya di Ambon, sehingga telah menjadi publik domein. Desain yang telah menjadi publik domein ini akan sangat riskan untuk diajukan pendaftarannya karena kemungkinan dapat diajukan keberatan oleh pihak ketiga berdasarkan Pasal 26 ayat (1) UU Desain Industri.

Kreatifitas dari pengrajin untuk menciptakan desain baru yang sering kali merupakan perbaikan-perbaikan atau pengembangan dari desain-desain yang telah ada memberikan peluang untuk diterima pendaftarannya, maka desain-desain yang baru diciptakan dapat dimintakan perlindungan jika didaftarkan,

Produk-produk kerajinan kerang mutiara stiap tahun pengrajin bersama Disperindag Kota Ambon melakukan pemasaran lewat event-event pameran baik lokal, nasional maupun internasional sehingga mempromosikan kerajinan kerang mutiara dalam negeri maupun Luar negeri. Perlu diperhatikan kemudian adalah ketentuan yang ada dalam Pasal 2 ayat (3) UU Desain Industri menyatakan bahwa yang termasuk dalam arti pengungkapan sebelum didaftarkan adalah salah satunya telah diumumkan atau digunakan di Indonesia atau diluar Indonesia. hal tersebut diperjelas dengan Pasal 3 UU Desain Industri yang termasuk dalam pengecualian terhadap ketentuan dalam Pasal 2 ayat (3) UU Desain Industri tersebut adalah dalam jangka waktu paling lama 6 bulan sebelum tanggal penerimaan, desain tersebut telah:

1) Dipertunjukan dalam pameran baik di Indonesia maupun luar negeri yang resmi atau diakui resmi

2) Digunakan di Indonesia dalam rangka percobaan dengan tujuan pendidikan, penelitian, atau pengembangan.

Ketentuan dalam Pasal 2 ayat (3) dan Pasal 3 UU Desain Industri, dapat menyebabkan terhadap desain-desain baru yang masih belum menyebar tersebut tidak dapat dimintakan perlindungan hukum, karena adanya kebiasaan bahwa desaindesain baru telah dipesan atau telah dijual ke konsumen. Berbagai hasil desain industri kerajinan kerang mutiara tersebut agar dapat dilindungi haruslah secara utuh memenuhi unsur:

1) Ketentuan dalam Pasal 1 ayat (1) UU Desain Industri

2) Kebaruan dalam Pasal 2 ayat (1) dan (2), Pasal 3 UU Desain Industri

3) Tidak bertentangan dengan peraturan perundang-undangan yang berlaku, 
ketertiban umum, atau kesusilaan (Pasal 4 UU Desain Industri)

4) Belum menjadi publik domein, sehingga tidak aka ada pengrajin keberatan pada saat didaftarkan.

Syarat-syarat di atas merupakan syarat kumulatif untuk dapat diterimanya suatu pendaftaran desain industri. Desain industri yang termasuk dalam kelompok Industrial Right menganut sistem perlindungan fist to file yaitu memberi perlindungan ekslusif berkaitan dengan hak moral dan hak ekonomi pada pendaftar pertama. Arti penting yang mendasari perlunya perlindungan hak morak dan hak ekonomi diberikan kepada pendaftar pertama adalah merupakan pengakuan terhadap karya intelektual seseorang pendesain atas upaya kreatif, waktu, tenaga dan biaya yang terkandung pada setiap karya dari kemungkinan adanya penggunaan secara illegal.

Hak ekonomi yang diatur dalam UU Desain Industri diberikan kepada pendaftar pertama yang berhasil menemukan desain industri baru, dan hak desain industri ini bersifat eksklusif. Penghargaan dalam bentuk hak eksklusif untuk menikmati manfaat ekonomi ini sejalan dengan "reward theory" dan "recovery theory"8 yang dikemukakan Robert M. Sherwood, namun sifat eksklusif dalam hak pendesain tidak bersifat penuh karena ada pembatasan yang mengandung fungsi sosial seperti yang terdapat di dalam Pasal 9 ayat (2) UU Desain Industri.

\footnotetext{
Memiliki makna berupa pengakuan terhadap karya intelektual yang telah dihasilkan oleh seseorang sehingga kepada penemu/pencipta atau pendesain harus diberikan penghargaan sebagai imbalanlan atas upaya-upaya kreatifnya dalam menemukan/menciptakan karya-karya intelektual tersebut

8 Penemu/pencipta/pendesain yang telah mengeluarkan waktu, biaya serta tenaga dalam menghasilkan karya intelektualnya harus memperoleh kembali apa yang telah dikeluarkannya tersebut .
}

Ketentuan Pasal 9 ayat (2) UU Desain Industri menyebutkan bahwa:

"Dikecualikan dari ketentuan sebagaimana dimaksud dalam ayat (1) adalah pemakaian Desain Industri untuk kepentingan penelitian dan pendidikan sepanjang tidak merugikan kepentingan yang wajar dari pemegang hak Desain Industri”.

Penjelasan umum juga menyebutkan bahwa "Pemakaian yang dimaksud di sini adalah pemakain hanya untuk kepentingan penelitian dan pendidikan, termasuk di dalamnya uji penelitian dan pengembangan. namun, pemakaian itu tidak boleh merugikan kepentingan yang wajar dari Pendesain, sedangkan yang dimaksud dengan "kepentingan yang wajar" adalah penggunaan untuk kepentingan pendidikan dan penelitian itu secara umum tidak termasuk dalam penggunaan hak Desain Industri sebagaimana dimaksud dalam ayat (1). Dalam bidang pendidikan, misalnya, kepentingan yang wajar dari Pendesian akan dirugikan apabila lembaga pendidikan yang adas di kota tersebut. Kriteria kepentingan tidak semata-mata diukur dari ada tidaknya unsure komersial, tetapi juga dari kuantitas penggunaan."

UU Desain Industri yang memberikan perlindungan bagi pendesain untuk menikmati manfaat ekonomi dan hakhak lainnya yang di miliki pendesain diharapkan dapat mendorong kreatifitas di bidang desain industri kerajinan kerang mutiara, sehingga dapat dihasilkan berbagai desain-desain kerajinan kerang mutiara yang unggul dan bermutu yang menduduki industri kerajinan kerang mutiara yang lebih modern. Perlindungan hukum terhadap hak untuk menikmati manfaat ekonomi tersebut sejalan dengan "incentive theory." Teori ini mengaitkan pemberian insentif bagi para

9 Mengaitkan pengembangan kreatifitas dengan memberikan insentif bagi para penemu/pencipta atau pendesain kerajinan kerang mutiara. Berdasarkan teori ini insentif perlu diberikan untuk mengupayakan terpacunya kegiatankegiatan penelitian yang berguna . 
pendesain yang bertujuan untuk memacunya kegiatan-kegiatan penelitian atau pengembangan yang berguna bagi perkembangan bentuk atau motif desain kerajinan kerang mutiara yang unggul dan bermutu.

Hak atas desain industri tercipta karena pendaftaran dan hak eksklusif atas suatu desain akan diperoleh karena pendaftaran. Pendaftaran adalah mutlak untuk terjadinya suatu hak desain industri. Oleh karena itu sistem pendaftaran yang di anut UU Desain Industri adalah bersifat konstitutif, yakni sistem yang menyatakan hak itu baru terbit setelah dilakukan pendaftaran yang telah mempunyai kekuatan hukum. Sistem konstitutif lebih menjamin adanya kepastian hukum dan ketentuan yang menjamin keadilan. ${ }^{10}$

Hak desain industri diberikan atas dasar permohonan, yang diatur dalam Pasal 10 UU Desain Industri, dan pihak yang untuk pertama kali mengajukan permohonan dianggap sebagai pemegang hak desain industri, kecuali jika terbukti sebaliknya sebagaimana dalam Pasal 12 UU Desain Industri. Konsekuensi yuridis dari tidak efektifnya ketentuan Pasal 10 jo Pasal 12 UU Desain Industri yang mengatur prihal pendaftaran hak (first to file) yaitu tidak dilakukannya pendaftaran hak atas karya desain industri oleh pendesainnya berakibat pendesain tidak mendapat perlindungan hukum dan secara yuridis tidak berhak atas karya desainya. Perlindungan hukum akan berada pada pihak yang melakukan pendaftaran atas karya tersebut dan memiliki bukti sertifikat pendaftaran.

Bentuk upaya perlindungan hukum dalam melindungi hak Desain Industri Kerajinan Kerang Mutiara berdasarkan teori perlindungan hukum yang dikemukakan oleh Philipus M. Hadjon adalah terdiri atas 2 (dua) bentuk perlindungan hukum, yaitu:

10 Pipin Syarifin dan Dedah Jubaedah, Perlindungan Hak Kekayaan Intelektual, (Bandung: Pustaka Bani Quraisy, 2004), hal. 175
1) Perlindungan Hukum Preventif

2) Perlindungan Hukum Represif

Perlindungan hukum yang dilakukan pengrajin kerang mutiara untuk mendapatkan hak desain industri secara preventif meliputi inisitaif mendaftarkan HaKI serta mengikuti pembinaan HaKI, namun sampai saat peneliti melakukan penelitian para pengrajin kerang mutiara belum mendaftarkan hasil karyanya berupa kerajinan kerang mutiara untuk dilindungi Undang-Undang HaKI yang berlaku di Indonesia. Upaya mendaftar desain industri kerajinan kerang mutiara merupakan cara yang sesuai dengan UU Desain Industri bahwa syarat agar desain mendapat perlindungan hukum adalah dengan mendaftarkannya, namun kesadaran pengrajin untuk mendaftarkan desain kerajinan kerang mutiara sangat rendah, sebagaimana yang terdapat di Disperindag sampai saat ini belum ada pengrajin kerang mutiara yang mendaftarkan desain kerajinan kerang mutiaranya ${ }^{11}$. Upaya pengrajin untuk melindungi desain kerang mutiara berupa perlindungan secara individual oleh pengrajin, yaitu: ${ }^{12}$

a) Pendokumentasian pada setiap desain baru yang dibuat dan diciptakan. Pendokumentasian ini selain berfungsi sebagai buku pemilik atas desain tersebut juga sebagai alat promosi bagi konsumen untuk menentukan dan memilih motif desain yang diinginkan.

b) Sikap kehati-hatian dalam melindungi kerahasiaan desain kerajinan kerang mutiara (hal ini ditunjukkan oleh beberapa pengrajin). Sikap kehati-hatian ini timbul akibat terlalu seringnya desain-desain yang baru dibuat dijiplak oleh pengrajin lain, baik yang berasal dari satu daerah ataupun yang berasal dari luar daerah.

Data yang penulis peroleh dari pemilik dan penanggungjawab industri

11 Ibid.

12 Data primer yang diolah berdasarkan hasil wawancara dengan pengrajin KKM. 
kerajinan kerang mutiara menunjukan indikasi yang sama yaitu secara keseluruhan pengrajin kerang mutiara tidak melakukan pendaftaran desain industri atas produkproduk kerajinan kerang mutiara yang mereka hasilkan. Alasan yang mendasari hal tersebut adalah: ${ }^{13}$

a) Ketidaktahuan dalam hal pentingnya melakukan pendaftaran baik manfaat yang akan diperoleh serta prosedur untuk mendapatkan perlindungan tersebut, selain hal tersebut sikap ketidakpercayaan pengrajin terhadap jaminan akan mendapat perlindungan, bahkan apabila kemudian akan dikenakan pungutan-pungutan liar (pungli)

b) Dalam praktek untuk mendapatkan sertifikat hak desain industri menyita waktu sehingga lebih berguna apabila dimanfaatkan untuk bekerja daripada mengurus pendaftarannya.

c) Permasalahan biaya bagi pendaftar bidang usaha ini dianggap memberatkan pengrajin, apabila hasil produksi dari tiap produk masih belum konsisten dengan kata lain ditolak atau disempurnakan sesuai UU Desain Industri.

Upaya lain pengrajin dalam memperoleh perlindungan desain industri adalah dengan aktif mengikuti pembinaan HaKI yang dilakukan pihak LSM, dengan aktif mengikuti pembinaan diharapkan para pengrajin semakin paham akan pentingnya perlindungan desain industri kerajinan kerang mutiara, serta mengetahui teknis pendaftarannya, namun usaha pengrajian yang aktif mengikuti pembinaan HaKI enggan mengikuti pembinaan HaKI yang nantinya bisa meningkatkan pemahaman mereka tentang desain industri. Selain upaya yang melibatkan pengrajin, terdapat upaya yang membutuhkan campur tangan pemerintah dalam hal ini bantuan berupa perhatian dan pengawasan yang intens dari pemerintah kota melalui dinas terkait terhadap keberadaan industri kerajinan kerang mutiara, terutama masalah perlindungan desain kerajinan kerang mutiara agar tindakan penjiplakan di kalangan pengrajin bisa diminimalisir.

Fenomena preventif yang telah diuraikan tersebut terdapat peluang terjadinya masalah pembajakan di bidang usaha kerajinan kerang mutiara sangat besar terjadi dan masalah kepemilikan hak-hak atas produk desain kerajinan kerang mutiara menjadi mengambang karena tidak didaftarkan.

Penyelesaian sengketa terhadap tindakan peniruan/pemalsuan, sebagaimana yang kita ketahui bahwa penyelesaian sengketa bisa melalui jalur non litigasi dan jalur litigasi, sebagaimana dalam Pasal 47 UU Desain Industri bahwa "Selain penyelesaian gugatan sebagaimana dimaksud dalam Pasal 46 para pihak dapat menyelesaikan perselisihan tersebut melalui arbitrase atau alternatif penyelesaian sengketa". Penyelesaian sengketa ini biasanya pihak pendesain meminta agar para penjiplak untuk tidak melanjutkan perbuatannya, jika tetap dilanggar maka pendesain akan melanjutkan ke jalur hukum.

Diselesikan dengan jalur hukum (pengadilan) tidak dapat dilakukan karena secara legal formal hak atas desain diperoleh karena pendaftaran, walapun apabila para pengrajin telah mendaftarkan kerajinan kerang mutiara dan secara legal formal mendapatkan hak atas desain industri, pengrajin kerang mutiara tidak menyelesaikan dengan jalur hukum (pengadilan) mengingat proses yang dijalani cukup lama, selain itu untuk menempuh jalur hukum, para pengrajin biasanya terlebih dahulu mengukur seberapa besar pengaruh penjiplakan tersebut terhadap pesanan/permintaan pasar. Jika pengaruhnya tidak terlalu besar, maka pengrajin memilih untuk membiarkan saja. Masalah tersebut 
para pengrajin memeliki alasan dari jalur penyelesaian yang diambil bahwa: ${ }^{14}$

a) Dibiarkan saja kegiatan penjiplakan karena hanya merupakan pihak-pihak kecil kapasitasnya untuk dapat melebihi hasil produk kerajinan kerang mutiara yang bersumber dari pendesain pertama, selain itu karena terlalu berbelit-belit apabila diteruskan permasalahan penjiplakan.

b) Dengan di tiru maka berarti merupakan promosi dari produk untuk lebih terkenal dan memperoleh pangsa pasar yang lebih luas.

c) Dilakukan penyelesaian dengan cara mediasi atau teguran pada pihak yang memalsukan.

d) Penyelesaian secara hukum dilakukan apabila alternative penyelesaian sengketa lain tidak dapat terpenuhi secara baik, akan tetapi hal ini masih belum diterapkan sebab secara legal para pengrajin belum melaksanakan pendaftaran karya desain kerajinan kerang mutiara sehingga sulit untuk mendapatkan suatu kepastian hukum.

\section{Alternatif Perlindungan HaKi Terhadap Kerajinan Kerang Mutiara}

Sebagaimana telah diuraikan sebelumnya bahwa keberadaan UU Desain Industri untuk melindungi hak pendesain atau pemegang hak desain industri, begitu pula halnya dengan Pasal 10 UU Desain Industri yang mengatur Hak Desain Industri atas dasar Permohonan, artinya secara yuridis pendesain atau pemegang hak desain industri terhadap kerajinan kerang mutiara mempunyai hak atas desain industri kerajinan kerang mutiara maka wajib melaksanakan permohonan pendaftaran sehingga dapat dilindungi UU Desain Industri.

Demikian dalam tataran empiris hingga saat ini belum ada pemegang hak desain industri yang melaksanakan haknya

14 Data primer yang diolah berdasarkan hasil wawancara dengan pengrajin KKM. tersebut, yaitu pemegang hak desain industri tidak pernah melaksanakan amanat Pasal 10 UU desain Industri tersebut sehingga produk kerajinan kerang mutiara secara legal belum dapat dilindungi UU Desain Industri maka penulis menganalisi alternatif perlindungan HaKI terhadap produk kerajinan kerang mutiara diantaranya:

1) Hak Cipta

Sesuai Pasal 12 ayat (1) huruf $\mathrm{f}$ menyatakan bahwa seni rupa dalam segala bentuk seperti seni lukis, gambar, seni ukir, seni kaligrafi, seni pahat, seni patung, kolase, dan seni terapan merupakan ciptaan yang dilindungi dengan hak cipta. Perlindungan hak cipta timbul secara otomatis ketika suatu karya yang asli dari pencipta dimunculkan dalam suatu media nyata. Suatu hasil karya dikatakan asli dalam konteks hak cipta jika hasil karya tersebut berasal dari penciptanya yang asli dan tidak diambil dari berbagai karya yang sudah ada.

Produk kerajinan kerang mutiara merupakan hasil karya dari Raden Abdullah yang merupakan penciptanya yang asli, karena kerajinan kerang mutiara berlangsung secara turun temurun dan tidak hanya 1 orang melainkan sudah menjadi milik komunitas pengrajin kerang mutiara di Ambon khususnya Desa batu Merah

2) Merek

Merek Dagang dan Merek Jasa adalah meliputi kata-kata, nama, simbol, atayu bagian yang digunakan oleh perusahaan barang dan penyedia jasa untuk mengidentifikasi barang dan jasa mereka, dan untuk membedakanb barang dan jasa dari yang dijual oleh perushaan lain, pada kerajinan kerang mutiara ini yang dimaksud dengan Merek adalah Merek Dagang.

Berdasarkan Pasal 4 UU Nomor 15 Tahun 2001 menyatakan bahwa Merek tidak dapat didaftar atas dasar Permohonan yang diajukan oleh Pemohon yang beritikad baik, maka merek hanya dapat didaftar atas dasar 
permintaan yang diajukan oleh pemilik merek yang beritikad baik sehingga setiap pengrajin kerang mutiara dapat mendaftarkan merek atas produk kerajinan kerang mutiara mereka untuk membedakan dengan produk milik pengrajin yang lain, dengan demikian kerajinan kerang mutiara yang memilki kesamaan kekhasan dapat memilki beberapa merek, jadi meskipun kerajinan kerang mutiara bentuk atau motif yang sama tapi mereknya berbeda-beda.

Dikaitkan dengan ketentuan BAB VII tentang Indikasi-Geografis dan IndikasiAsal, maka dalam Pasal 56 tentang indikasi geografis, dimana indikasi geografis berbeda dengan merek. Indikasi geografis lebih merupakan tanda yang menunjukkan asal suatu barang yang karena faktor geografis termasuk faktor alam, faktor manusia atau kombinasi dari kedua faktor geografis termasuk faktor alam, faktor manusia atau kombinasi dari kedua faktor tersebut telah memberikan ciri dan kualitas tertentu pada barang yang dihasilkan.

Tanda yang digunakan sebagai indikasi dapat berupa etiket atau lebel yang dilekatkan pada barang yang dihasilkan. Tanda tersebut dapat berupa nama, tempat, daerah atau wilayah, kata, gambar, huruf, atau kombinasi dari unsur-unsur tersebut. Kerajinan kerang mutiara sudah menunjukkan indikasi geografis yaitu kerang mutiara yang berasal dari laut Maluku, jika hal tanda yang seharusnya dilindungi berdasarkan indikasi geografis namun tidak didaftarkan, maka perlindungan terhadap tanda tersebut berdasarkan indikasi asal sebagaimana dalam Pasal 59 ayat (1) dan (2) bahwa Indikasi asal dilindungi sebagai suatu tanda yang memenuhi ketentuan Pasal 56 ayat (1), tetapi tidak didaftarkan atau semata-mata menunjukkan asal suatu barang atau jasa.

Menurut penulis berbicara mengenai bentuk perlindungan hukum khususnya dalam konteks perlindungan hukum HaKI atas desain industri kerajinan kerang mutiara, maka kita harus kembali lagi melihat filososi dari perlindungan hukum itu sendiri, dimana perlindungan hukum merupakan salah satu wujud misi hukum dalam konteks menegakkan keadilan didalamnya, itu berarti perlindungan hukum diwujudkan berdasarkan hukum yang adil, sebagaimana teori keadilan yang dikembangkan oleh John Rawls ${ }^{15}$ bahwa hukum harus memberikan keuntungan kepada kelompok masyarakat yang kurang beruntung, sementara dalam UU Desain Industri kita terjadi ketidak signifikan antara pengaturan hukum yang belum nyata bagi $\mathrm{UKM}^{16}$ merupakan suatu hal yang sangat disayangkan, sebab salah satu alasan dikeluarkannya UU tentang Desain Industri justru untuk menampung karya intelektual yang datang dari lapisan masyarakat yang luas, termasuk dalam hal ini pendesain dari kelompok $\mathrm{UKM}^{17}$ khususnya pengrajin kerang mutiara, namun kelompok UKM-lah khususnya pengrajin kerang mutiara yang tergolong belum banyak memperoleh manfaat dari kehadiran hak desain industri sehingga hak cipta dan merek merupakan alternatif perlindungan HaKI terhadap produk kerajinan kerang mutiara.

${ }^{15}$ John Rawls. Theory of Justice, (New York: Oxford University Press Inc, 1971), hal. 35. Dalam Muhammad Syaifuddin. Perlindungan Hukum Hak Masyarakat Kurang dan Tidak Mampu atas Pelayanan Kesehatan Rumah Sakit Swasta Berbadan hukum Perseroan Terbatas, Ringkasan Disertasi Program Doktor Ilmu Hukum Pascasarjana Universitas Brawijaya, Malang, 2008, hal. 7

16 Setelah pendaftaran desain industri dibuka sejak Juni tahun ini sampai 19 Oktober yang lalu, tercatat 947 dengan rincian sebagai berikut : 713 permohanan dari dalam negeri dan 234 permohonan dari luar negeri (Namun, dari sejumlah permohonan dalam negeri tersebut, hanya dua yang berasal dari kelompok UKM. A. Zen Umar Purba. Makalah, Disampaikan pada acara Peresmian SME Center dan Panel Diskusi, Jakarta, 7 November 2001

${ }^{17}$ Bagian Menimbang UUDI Nomor 31 Tahun 2000. Selain itu, biaya pendaftaran untuk karya yang berasal dari UKM hanya separuh dari biaya untuk non UKM. 


\section{P E N U T U P}

Bentuk perlindungan hukum khususnya dalam konteks perlindungan HaKI atas desain industri kerajinan kerang mutiara, sampai saat ini para pengrajin kerang mutiara belum mendaftarkan desain kerajinan kerang mutiara untuk dilindungi UU Desain Industri.

Hak ekonomi yang diatur dalam UU Desain Industri diberikan kepada pendaftar pertama yang berhasil menemukan desain industri baru, dan hak desain industri ini bersifat eksklusif. Penghargaan dalam bentuk hak eksklusif untuk menikmati manfaat ekonomi ini tidak sejalan dengan "reward theory" dan "recovery theory", namun para pendesain mampu berkreatifitas di bidang desain industri kerajinan kerang mutiara, sehingga dapat dihasilkan berbagai desain-desain kerajinan kerang mutiara yang unggul dan bermutu yang menduduki industri kerajinan kerang mutiara yang lebih modern sehingga incentive theory dapat terwujud.

Bentuk upaya perlindungan hukum dalam melindungi hak Desain Industri Kerajinan Kerang Mutiara secara :

1) Perlindungan hukum preventif, pengrajin untuk melindungi desain kerang mutiara berupa perlindungan secara individual dan mengikuti program pembinaan dan pengembangan HaKI di masyarakat dalam hal ini pengrajin kerang mutiara terhadap Industri Kecil dan Menengah (IKM)

2) Perlindungan hukum represif yaitu para pengrajin memeliki alasan dari jalur penyelesaian yang diambil dengan cara mediasi atau teguran pada pihak yang memalsukan.

3) Hak Cipta dan Merek sebagai alternative perlindungan haKI terhadap produk kerajinan kerang mutiara.

\section{DAFTAR PUSTAKA}

\section{Buku}

Ahmad M. Ramli. Teori Dasar Perlindungan Rahasia Dagang, Bandung: Mandar Maju, 2000.

B.N. Marbun. Kekuatan dan Kelemahan Perusahaan Kecil: Mengapa Ribuan Perusahaan Kecil Rontok Setiap Tahun, Jakarta: Pustaka Binaman Pressindo, 1993.

Bambang Waluyo. Penelitian Hukum dalam Praktek, Jakarta: Cetakan kedua, Sinar Grafika, 2002.

Budi Agus Riswandi; M. Syamsudin. Hak Kekayaan Intelektual dan Budaya Hukum, Jakarta: Raja Grafindo Persada, 2005.

Bambang Sunggono. Metode Penelitian Hukum, Jakarta: Raja Grafindo Persada, 2007.

C. Van Peursen. Strategi Kebudayaan, (Terjemahan) Dick Hartoko, Jakarta-Yogyakarta: BPK Gunung Mulia-Kanisius, 1985.

Deddy S Bratakusumah; Dadang Solihin. Otonomi Penyelenggaraan Pemerintah Daerah, Jakarta: Gramedia Pustaka Utama, 2003.

Esmi Warassih. Pranata Hukum Sebuah Telaah Sosiologis, Semarang: Suryandaru Utama, 2005.

Endang Purwaningsih. Perkembangan Hukum Intellectual Property Rights, Bogor: Ghalia Indonesia, 2005.

Ignatius Haryanto. Penghisapan Rezim HaKI, Yogyakarta: Kerjasama Debt-Wtch Indonesia dengan Kreasi Wacana, 2002.

Johny Ibrahim. Teori \& Metodologi Penelitian Hukum Normatif, Malang: Edisi revisi, Cetakan Kedua, Bayumedia, 2007.

Koentjoroningrat. Kebudayaan, Mentalitas, dan Pembangunan, Jakarta: Gramedia, 1981. 
Lawrence M Friedmen. The Legal System A Social Perpective, New York: Russell Sage Foundation, 1975.

Lexi J. Moleong. Metode Penelitian Kualitatif, Bandung: Remaja Roosdakarya, 1995.

Lili Rasjidi, Dasar-Dasar Filsafat Hukum, Bandung: Citra Aditya Bakti, 1996

Muhammad Djumhana. Hukum Ekonomi Sosial Indonesia, Bandung: Citra Aditya Bakti, 1994.

Muhammad Djumhana; R. Djubaedillah. Hak Milik Intelektual: Sejarah Teori dan Prakteknya di Indonesia, Bandung:.Citra Aditya Bakti, 2003.

Muhammad Syaifuddin. Perlindungan Hukum Hak Masyarakat Kurang dan Tidak Mampu atas Pelayanan Kesehatan Rumah Sakit Swasta Berbadan hukum Perseroan Terbatas, Ringkasan Disertasi Program Doktor Ilmu Hukum Pascasarjana Universitas Brawijaya, 2008.

O.K. Saidin. Aspek Hukum hak Kekayaan Intelektual, Jakarta: Rajawali Press, 2007.

Pipin Syarifin dan Dedah Jubaedah. Perlindungan Hak Kekayaan Intelektual, Bandung: Pustaka Bani Quraisy, 2004.

Philipus M. Hadjon. Perlindungan Hukum Bagi rakyat Indonesia, Surabaya: Peradaban, 2007.

Satjipto Rahardjo. Ilmu Hukum, Bandung: Alumni, 2006.

Sudargo Gautama. Segi-Segi Hukum Hak Milik Intelektual, Bandung: Erisco, 1995.

Suyud Margono; Amir Angkasa. Komersialisasi Aset Intelektual Aspek Hukum Bisnis. Jakarta: Grasindo, 2002.

Yoan Nursari Simanjuntak. Hak Desain Industri: Sebuah Realitas Hukum dan Sosial, Surabaya: Srikandi, 2006.
Yayasan Klinik HaKI (IP Clinic). Kompilasi Undang-Undang Hak Cipta, Paten, Merek dan terjemahan Konvensi-Konvensi di Bidang Hak atas Kekayaan Intelektual (HaKI), Bandung: Citra Aditya Bakti, 2006.

\section{Jurnal dan Makalah}

Menteri Perindustrian dan Perdagangan. Sambutan Pengarahan Menperindag pada RAKORNAS RISTEK, Diselenggarakan oleh Kantor Menristek , tanggal 10-12 Agustus 1999.

Mudrajad Kuncoro. Usaha Kecil Di Indonesia: Profil, Masalah Dan Strategi Pemberdayaan, Makalah, Tanpa Tahun

Sentot P. Sigito. Perlindungan dan Pemberdayaan Hak Kekayaan Intelektual Tradisional, Arena Hukum; Meret 2000;

Sukarmi. Aspek-Aspek Hak atas Kekayaan Intelektual dalam Industri Multimedia, Arena Hukum; Meret 2000;

Sihabudin. 2008. "Peluang dan Prospek Pengembangan Usaha kecil di Jawa Timur serta HambatanHambatan Pemanfaatan Dana dari Lembaga Keuangan Bagi UMKM". Makalah disampaikan pada Seminar Nasional "Hukum dan Kebijakan Pengembangan Litbang untuk sector Usaha Kecil dan Menengah Guna Peningkatan Kemampuan Perekayasaan, Inovasi, serta Difusi Teknologi”, Diselenggarakan atas Kerjasama FH-UB dengan Kementerian Negara RISTEK RI, Malang, 23 Oktober.

Syahlan A. Sume. Manajemen Usaha Kecil \& Menengah, Modul I, Pusat Pengembangan Bahan AjarUMB,Tanpa Tahun 


\section{Internet}

Aswin. Review Terhadap Rencana Revisi Undang-Undang Hak Atas Kekayaan Intelektual, http://aswinsh.wordpress.com/200 9/01/06/review-terhadap-rencanarevisi-undang-undang-hak-ataskekayaan-intelektual/,

Deden Gunawan. Karya RI Dipatenkan Asing; Berkarya di Tengah Ancaman Hukuman, http://www.detiknews.com,

http://www.herdiansyah.org/2009/10/disemi nasi-makna-mafia peradilan.html,

http://id.wikipedia.org/wiki/Pertahanan_hidu http://id.wikipedia.org/wiki/GATT,

Yanu E Prasetyo. Miskin, Litbang, dan Pemberdayaan, http://suarapembaca.detik.com,

Zaedatur Rohmah. 2005. Aspek Perlindungan Hukum Desain Tradisional, http://digilib.umm.ac.id/gdl.php? $\underline{\text { mod=browse\&op }=\text { read\&id=jiptu }}$ mmppgdls12005zaedaturro3041\& HPSESSID=42d6ee65b827a38f44 956092d28ba985,

\section{Perundang-Undangan}

Undang-Undang Dasar 1945

Undang-Undang Tentang Larangan Praktek Monopoli dan Persaingan Usaha Tidak Sehat. UU Nomor 5 Tahun 1999

Undang-Undang Tentang Desain Industri. UU Nomor 31 Tahun 2000

Undang-Undang Tentang Hak Cipta. UU Nomor 19 Tahun 2002 Tentang Hak Cipta

Undang-undang Tentang Pemerintahan Daerah. UU Nomor 32 Tahun 2004
Undang-Undang Tentang Usaha Mikro, Kecil dan Menengah. UU Nomor 20 Tahun 2008

Peraturan Daerah Kota Ambon Tentang Rencana Pembangunan Jangka Panjang Kota Ambon. Perda Kota Ambon Nomor 4 Tahun 2006

Peraturan Daerah Kota Ambon Tentang Rencana Pembangunan Jangka Menengah Kota Ambon. Perda Kota Ambon Nomor 2 Tahun 2007 